\title{
Politics of Critique: Understanding Gender in Contemporary Middle East
}

\section{Özlem Altan-Olcay}

Since late 2010, we have witnessed an extraordinary unfolding of events in the Middle East. Starting with widespread mobilizations against authoritarian regimes, demands for dignity and improved socioeconomic circumstances, events have taken a turn for the worse. As Egypt's military government consolidates power, the Syrian crisis shows no sign of resolution and ISIS's areal control expands, the need to appreciate the politics of representation and critique is evident. In this paper, I want to explore the following question: how do we reflect on the gendered ramifications of this turn of events? What tools do we have to problematize the transition from women's vociferous demands for equality to counterrevolutionary challenges to women's rights?

In this pursuit, I am interested in exploring the implications of spatial production of academic knowledge, by thinking reflexively about critiques of Orientalist discourses, emerging from postcolonial studies and scholarship on varieties of democratization. I contrast their success in challenging racist perceptions in the West, especially concerning the figure of the exotic "Middle Eastern/Muslim woman," with the ways in which this knowledge production travels and is reconfigured in places where power inequalities are different. My goal is to think about ways of recognizing the familiar demands of secular, liberal or socioeconomically egalitarian democracies, while still unmaking the "exotic Muslim woman." This, I propose, may help us in our efforts to make sense of contemporary events, moving beyond articulations of "how not to" understand things. 


\section{Challenging "the Oriental woman"}

The recent wave of revolutionary mobilization has challenged thoroughly Orientalist perceptions about the Middle East. The spectacles we witnessed were reflections of societies, not defined by a culture prone to authoritarianism and alien to notions, such as diversity, individual rights and freedom. Instead, people were organizing across ideological differences, finding in each other's company new possibilities for solidarity. Scholars, who objected to the term "Arab Spring", reminded us that these demands for participatory politics and economic dignity have been there for a long time (Bayat 2013; Hudson 2011).

Women were at the front lines of every aspect of this mobilization. They protested violence against women and demanded gender equality in legal and everyday practices. Their active participation ran counter to racist images of "the Middle Eastern woman" immersed in her subjugation and unknowingly participating in its making. The mixed gender encounters of the city squares and the civilian measures taken to ensure women's safe participation attested to the fact that these were not monolithic cultures with gender-unequal norms and practices. Rather, gender inequalities stemmed from institutionalized, repressive practices and targeted intimidation of women as a strategy to weaken opposition. These mobilizations revealed complex and heterogeneous experiences and articulations of gendered agencies.

These observations attest to decades of scholarly writing, which, following in the footsteps of Edward Said's Orientalism, show that the Middle East is not a homogenous entity, standing as the "unenlightened" other of a "civilized West" (Said 1979). In this scholarship, I would like to tease out two discussions around questions of women, showing their power for challenging the aforementioned clichés, while also pointing out risks. First, this scholarship has 
challenged the seemingly neat separation of "the Occident" and "the Orient," exposing how colonial ideology and violence were integral to Western enlightenment (McClintock 1995). It has also shown how Western geopolitical interests have been complicit in the resilience of unpopular regimes (Enloe 1989), often producing legitimizing narratives of "modernizing" and "enlightened leaders." These regimes have historically introduced, in a paternalist manner, some women's rights as part of this narrative of modernization. Because these actions have benefited only a small fraction of women in these polities (Tekeli 1981), the upshot has been that focusing on these urban elite actors, at the expense of bulk of women, would reproduce exclusionary tendencies of authoritarian regimes. Second, this literature has problematized colonial and contemporary transnational liberal feminist discourses' individualist assumptions regarding agency, exposing their neglect of global and local political economic inequalities and associated violences (Grewal 2005; Mohanty 2003; Alexander and Mohanty 1997). This critical literature has accounted for how ordinary women creatively practice their agencies and open up space for themselves in the everyday (Abu Lughod 2004). Accordingly, achieving agency did not necessarily lie in discovering individualist modernity, emancipation from family, tradition and/or religion (Chakrabarty 2000; Deeb 2006; Mahmood 2004). These calls for uncovering historical continuities and the hypocrisy of narratives of modernization, usually adopted by local elite to legitimize their repressive strategies, and for celebrating pluralist understanding of agency, have been vital.

Yet, there are also problems that relate to ways in which we can and cannot explain contemporary events. I find two critiques especially important. First, Kandiyoti (2015) makes a significant intervention when she unpacks the problematic relationship between early feminist mobilization, colonial powers, and post-independence state elite. She draws attention to 
substantial power inequalities between them, an observation which should caution us against thinking of civilian participants of state feminism as dominant movements that exercised comparable power. This is important especially at the contemporary juncture because many counterrevolutionary forces in the region are engaging in attempts to silence women and their demands for equality by accusing them of being subservient to remnants of past corrupt regimes or imperialistic agendas (Pratt 2013). As one political actor after another publicly blames women protestors for the violence inflicted on their bodies, delegitimizing their public presence and demands by making references to the "cultural place" of women, simply protesting these unfortunate discourses is inadequate. We must start with the historical continuities in such discourses and emphasize the struggles women have engaged for their rights (Narayan 1997). This requires paying attention to the diversity of demands and ideological positions, highlighting the complexity of women's conundrums.

This takes me to a second, interrelated critique. Abbas (2014) discusses how in postcolonial scholarship, "left-liberalism's intense anxiety about doing right by Muslims" translates into a tendency to, first, acknowledge the wide varieties in women's subjectivities in relation to religion and piety (2014: 53), and then to almost exclusively devote attention to orthodox Muslim women. She shows how this tendency sometimes promotes the idea that practices of conformity as an expression of agency are equally as valid as "Western" expectations of resistance. At other times, it goes to the extent of critiquing reformist Muslims and secular feminist actors as Westernized compradors. Yet at other times, it engages in a "no worse than the West" brand of politics (Abbas 2014). Exclusive argumentation in this manner has a political implication in the region, however. It inadvertently lends a hand to locally based arguments by 
political actors on women's roles in these cultures; how women should find dignity in families and piety; and how secular demands do not reflect the wishes of the majority.

These critiques are important in understanding the events of the past few years. The nature of the demands people made; the initial absence of Islamist movements from the squares; and the vociferous participation of women, choosing resistance to and not compliance with the roles bestowed on them, reflected a different, pluralistic practice of agency, not one of heavily dominated by assertions of conformity or cultural difference. People demanded changes that seemed uncannily close to characteristics of liberal and/or social democracies. When the stereotypical representations in the Western media conjured, once again, the image of the "Middle Eastern woman's awakening," many scholars critiqued them and rightfully so. Can we do more than engage in a politics of negation; is there more to be done to document the genealogy of today's complexities? To that end, Abu Lughod (2013) emphasizes the need to challenge the "Muslim woman" trope, by drawing on the multiplicity of women's experiences at the intersection of religiosities, nationalisms, and exigencies of global political economy. This, for instance, reveals the importance of studying how Muslim feminists are actively engaged in reinterpreting Islam to expand women's rights (Badran 2009; Ong 2007). My question is the following: how do we address this challenge further without overemphasizing, this time, "Muslim women" instead of "the Muslim woman?"

\section{Democratizing approaches to democracy}

In addition to postcolonial critique, a different literature on varieties of democracies has also suggested that not all democracies had to be modelled after those in Western Europe and North America. For instances involving Muslim majority societies, by posing that there will be varieties 
with respect to culture, this approach is able to forestall accusations of Westernization against domestic pro-democracy forces. By arguing that democratization is possible in the Middle East, it challenges Orientalist discourses about the regional cultures' incompatibility with democracy and citizenship rights.

This scholarship is based on the works of many who delineated the problems of assuming a monolithic Islam as a force opposed to democratization (Hudson 1995; Sadiki 2004). Even before the mobilizations began, there was focus on the willingness of moderate Islamist actors' to participate in electoral processes (Nasr 2005). Observations of generational changes and progressive reinterpretations of Islam emerging in internal debates demonstrated that some Islamist actors were willing to accept pluralism in culturally specific terms (Wickham 2011). This scrutiny has intensified with the onset of the uprisings, successfully bringing back to discussions previously excluded political actors.

However, again, there is much about which to suggest caution. Here, it is the silences that are interesting. First, assumptions about cultural specificities risk a reluctance to expose political mechanisms that consolidate certain practices under the rubric of culture. This reluctance can also deemphasize voices in the region, demanding democratic rights and defining them in ways that sound close to "Western" models. A second set of questions is about what the contextually specific differences of "Middle Eastern" democracies might be. Here the problem is more of a silence on issues of gender, relegated implicitly to the sphere of culture. Histories of nationalism reveal how women have been seen as cultural repositories in processes of nation-state making, with the effect of producing unequal rights for women and men (Yuval-Davis 1998). This should be a warning to us about the dangers of sensitivity to "unique cultural circumstances" in discussions of democratization. Swinging the pendulum too far in the direction of cultural 
varieties and relegating gender in the realm of unspoken culture risks depoliticizing issues of gender based equality and freedom (Candaş and Silier 2014). This time the problem is not one of overemphasizing "Muslim women," but one of erasure; an erasure of both Muslim women's activisms and others, who refuse religious frameworks in defining their rights.

\section{The place of critique}

How does all of this fit with what is happening in the region today? At this juncture, we have, on the one hand, the return of alarming stereotypes about "Arab violence" and "Arab men's misogyny." On the other hand, in response to these racist representations, critical work points out how extremist interpretations of Islam cannot speak in the name of whole societies; that Islam could not be the only explanation and that complex political economic realities should be taken into consideration (Seikaly and Mikdashi 2012). These challenges also emphasize the role of colonial pasts and US imperialism in the crisis that women find themselves in today (Al-Ali and Pratt 2011). These important counterarguments lead me to question if there is further room to formulate analyses that pay more attention to gendered battles and the agency of the people involved in them, in their local contexts, including but not limited Muslim feminists.

To that end, I want to reflect on the spatial configuration of academic knowledge and critique. I suggest that the arguments about complexity and agency in postcolonial literature have much to do with the immediacy of racism in the US and Western Europe toward the Middle East and "the Middle Easterner." Racism in everyday life, popular media, and its reproductions in global imperial politics inform the determination to break down stereotypes about homogenized "bad Muslims," to challenge the politics behind discourses of "moderate Muslims," and to critique Western modernity: the exclusionary nature of its assumptions about freedom and 
agency; the violence that accompanies its universalizing tendencies; and its limited tolerance of difference even as it claims otherwise.

In the case of the literature on democratization, from the 1990s onwards, many international organizations and Western governments increased funds to the region, for the purposes of supporting political liberalization, without upsetting regional balances and causing upheaval for "friendly" regimes. These were conflicting agendas. Security concerns meant that significant funding went to bolstering the military capacities of the states. Yet it was the same capacity that ended up creating horrific human rights concerns, which democracy promotion aimed to alleviate by supporting political pluralism through civil society organizations (Burnell and Schlumberger 2010; Durac 2009). Furthermore, these activities linked with only a limited range of organizations, resembling Western counterparts (Hawthorne 2004; Altan-Olcay and Icduygu 2012). When the hopes vested in this strategy did not bring about gradual democratization (Encarnación 2006), and "friendly" regimes became visibly problematic, discussions of moderate Islamic actors became pronounced.

Both concerns of Islamophobia and geopolitics have had uncanny effects on what has been deemphasized: discussions of gender-based inequality. Talking more about gender inequalities could challenge ideas of culturally specific democracies, risking affinity with dangerous discourses of universal desirability of so-called Western norms. Talking about coercive practices targeting women in the name of Islam could grease the wheels of Islamophobia. Drawing attention to the secular discontent of women in the region could run counter to critiques of modernity and modernization ideologies.

However, discourses travel, are adapted, and are put to political use in contextually specific ways, not necessarily confined to original intentions and audiences (Abbas 2014). 
Critiquing exclusionary tendencies of discourses of enlightenment in the West is not the same thing as rejecting them seemingly for the same reasons elsewhere. That is due to the contextually specific ways in which power inequalities operate. It is also why arguments defending genderspecific roles for Muslim men and women in the West, in conditions where they are weaker, can travel to a Sunni-Muslim majority society and become the basis of a defense of "our" cultural difference from the West, eventually evolving into an attack on those demanding more rights. Arguments in critique of enlightenment ideals in contexts where individual rights are under legal protection (not fully, but to a greater extent) can travel to contexts where they risk becoming the excuse for delegitimizing demands for such rights. Debates on "culturally suitable" democratic models risk another kind of Orientalism (Rumelili 2013), turning a blind eye to actual, concerted political action that produces what is "culturally acceptable" and not.

These observations render examination of how women deal with their circumstances urgent, but without excluding these circumstances' active political construction. I have three interrelated directions in mind. First, as Dirlik (1997) and Chibber (2014) suggest, we have to be more attentive to the workings of capitalism, locally articulated within a web of global connections. What are the ways in which capitalisms hinge on, reproduce gender inequalities, and their cultural articulations (White 2004, Karim 2011)? How are discourses of gendered divisions of labor consolidated by existing economic and social policies (Buğra and Yakut-Çakar 2010)? It is not enough to have a qualifier on political economic issues, capitalist violence, and complexities, before moving on to a full-fledged focus on politics of discourse and representation. In that sense, it might be important to shift the focus to "the background" against which differentiated agencies and strategies play out. Such an approach may help us historicize 
contemporary gender inequalities, in locally specific ways, without limiting ourselves to "it happens everywhere."

Second, in the realm of politics of discourse and representation, we should also take claims to cultural difference made by non-Western circuits of power more seriously. More attention should be paid to the ways in which critiques of cultural explanations of "backwardness" and "victimhood of women" are co-opted by various conservative actors into discourses of glory of "our cultures" and how "we treat our women much better than they do in the West." Besides speech-acts, we could also pay closer attention to law making (Joseph 2000), schooling (Abdella and Starrett 2007), the size and content of state and non-state religious services, their roles in consent production as well as coercion especially, in the realm of gender politics. Critical approaches have the tools to study such interactions much better than reactionary representations.

Finally, we need more work that pays attention to women and men critiquing discourses of tradition and religion, debating possibilities for liberalizing polities, and giving more rights to the individuals. To that end, how do women organize and resist the culturally normalized roles bestowed upon them? Under what conditions do we see the emergence of alliances across cleavages; what are the common demands and the limitations? What determines varying outcomes (Moghadam 2013)? Chibber's (2014) account of resistance in colonial histories reveals to us that people organize around their interests; however they may be articulated and contested in culturally specific ways. They do so under various structural constraints, affecting both their tactics and outcomes. Notwithstanding the plurality of practices of agency, I feel we need more room to study resistance, whose language and demands may actually contradict arguments about culturally specific definitions of agency. 
Thinking about the relationship between cultural representation and resistance, I am reminded of a conversation James Ferguson (2006) recounts, with a man during his fieldwork in Lesotho, whose desire for a "European-style" house the young Ferguson protests because it would be "a copy... of the culture of the colonizer" (2006:19). The man asks Ferguson about Ferguson's house, teasing out material inequalities between the anthropologist and himself. He then responds, "[t]hat is the direction we would like to move in." Ferguson (2006) describes the shift in the dialogue in this manner: "The aspiration to a "European" house, he forced me to see, was not a matter of blind copying; it was a powerful claim to a chance for transformed conditions of life - a place-in-the-world, a standard of living, a "direction we would like to move in" (2006: 19).

My suggestion is that we need to pay attention to the place-specific nature of critical debates in disentangling context specific power inequalities. Assertions of cultural difference in polities where non-white minorities face discrimination and political actors pursue imperial politics are also about challenging material inequalities and violence attached to cultural denigrations. Thus when the same cultural assertion claims travel to locations where local power balances are starkly different, this is something to take into consideration. This conclusion begets the counter question of whether anyone can be held accountable for how others take up her critique. Of course no one can be held responsible for how others abuse their ideas but I do think it is important to refine the dimensions of complexity, which critical scholarship seeks to do so, anyway. For it to be more visible, a possible rethinking of the goal of making the "exotic" familiar without exoticizing the familiar might be necessary.

Abbas, S., 2014. At Freedom's Limit: Islam and the Postcolonial Predicament. Fordham University Press. 
Abdella Doumato, E., Starrett, G., 2007. Teaching Islam: Textbooks and Religion in the Middle East. Colorado: Lynne Rienner.

Abu-Lughod, L. 2008. Dramas of Nationhood: The Politics of Television in Egypt. University of Chicago Press.

Abu-Lughod, L. 2013. Do Muslim Women Need Saving? Harvard University Press.

Al-Ali, N., Pratt, N., 2011. Conspiracy of Near Silence: Violence Against Iraqi Women. Middle East Report 258, 34-48.

Altan-Olcay, O., and Icduygu, A., 2012. Mapping Civil Society in the Middle East: The Cases of Egypt, Lebanon, and Turkey. British Journal of Middle Eastern Studies, 39(2), 157-179.

Alexander, M. J., Mohanty, C. T. (Eds.). 2013. Feminist Genealogies, Colonial Legacies, Democratic Futures. Routledge.

Badran, Margot., 2009. Feminism in Islam: Secular and Religious Conversions. Oneworld

Bayat, A., 2013. The Arab Spring and Its Surprises. Development and Change 44(3), 587-601.

Buğra, A., and Yakut-Çakar, B., 2010. Structural Change, the Social Policy Environment and Female Employment in Turkey. Development and Change 41(3), 517-538.

Burnell P., Schlumberger O., 2010. Promoting Democracy: Promoting Autocracy? International Politics and National Political Regimes, Contemporary Politics 16(1), 1-15.

Chakrabarty, D., 2000. Provincializing Europe: Postcolonial Thought and Historical Difference. Princeton University Press.

Chibber, V., 2014. Postcolonial Theory and the Specter of Capital. Verso.

Deeb, L., 2006. An Enchanted Modern: Gender and Public Piety in Shi'I Lebanon. Princeton University Press.

Dirlik, A., 1997. The Postcolonial Aura: Third World Criticism in the Age of Global Capitalism. Westview Press.

Durac, V., 2009. The Impact of External Actors on the Distribution of Power in the Middle East: The Case of Egypt, The Journal of North African Studies 14(1), 75-90.

Encarnación, O.G., 2006. Civil Society Reconsidered, Comparative Politics 38(3), 357-376.

Enloe, C., 1989. Bananas, Beaches and Bases: Making Feminist Sense of International Politics. University of California Press.

Ferguson, J., 2006. Global Shadows: Africa in the Neoliberal World Order. Duke University Press. 
Göle, N., 1996. The Forbidden Modern: Civilization and Veiling. The University of Michigan Press.

Grewal, I., 2005. Transnational America: Feminisms, Diasporas, Neoliberalisms. Duke University Press.

Hawthorne, A., 2004. Middle Eastern Democracy: Is Civil Society the Answer?. Carnegie Papers: Democracy and the Rule of Law Project, 44, 1-26.

Hudson., M.C., 1995. The Political Culture Approach to Arab Democratization: The Case for Bringing It Back In, Carefully in Rex Brynen, Bahgat Korany, and Paul Noble, eds., Political Liberalization and Democratization in the Arab World. Lynne Rienner Publishers, 61-76.

Hudson, M., 2011. Awakening, Cataclysm, or Just a Series of Events? Reflections on the Current Wave of Protest in the Arab World. Jadaliyya. http://www.jadaliyya.com/pages/index/1601/awakening-cataclysm-or-just-a-series-ofevents-refb (last accessed March 14, 2015)

Joseph, S., 2000. Gender and Citizenship in the Middle East. New York: Syracuse University.

Kandiyoti, D., 2015. The Triple Whammy: Towards the Eclipse of Women's Rights. Open Democracy. https://www.opendemocracy.net/5050/deniz-This/triple-whammy-towardseclipse-of-women\%E2\%80\%99s-rights (last accessed March 1, 2015)

Karim, L., 2011. Microfinance and Its Discontents: Women in Debt in Bangladesh. Minneapolis: University of Minnesota.

Mahmood, S., 2004. Politics of Piety: The Islamic Revival and the Feminist Subject. Princeton University Press.

McClintock, A., 1995. Imperial Leather: Race, Gender and Sexuality in the Colonial Conquest. Routledge.

Moghadam, V., 2013. What is Democracy? Promises and Perils of the Arab Spring. Current Sociology 61(4): 393-408.

Mohanty, C., 2003. Feminism without Borders: Decolonizing Theory, Practicing Solidarity. Duke University Press.

Narayan, U., 1997. Dislocating Cultures: Identities, Traditions, and Third World Feminism. Routledge

Nasr, V., 2005. The Rise of "Muslim Democracy.” Journal of Democracy 16 (2), 13-27

Ong, A., 2007. Muslim Feminism: Citizenship in the Shelter of Corporatist Islam. Citizenship Studies 3(3): 355-371. 
Pratt, N., May 6, 2013. Egyptian Women: Between Revolution, Counter Revolution, Orientalism, and "Authenticity". Jadaliyya. http://www.jadaliyya.com/pages/index/11559/egyptianwomen_between-revolution-counter-revoluti (last accessed March 14, 2015)

Rumelili, B., 2013. "Modelling Democracy: Western Hegemony, Turkey and the Middle East". In: Morozov, Viatchezlav (Eds.), Decentering the West: The Idea of Democracy and the Struggle for Democracy, 65-81. Surrey: Ashgate

Sadiki, L., 2004. The Search for Arab Democracy: Discourses and Counter-Discourses. London: Hurst \& Company

Said, E., 1979. Orientalism. Vintage Books.

Seikaly, S., Mikdashi, M., April 25, 2012. Let's Talk About Sex. Jadaliyya. http://www.jadaliyya.com/pages/index/5233/lets-talk-about-sex (last accessed March 5, 2015)

Tekeli, Ş., 1981. Women in Turkish Politics. In: Nermin Abadan-Unat (Eds.), Women in Turkish Society, 281-292. Leiden: E.J. Brill.

White, J., 1994. Money Makes Us Relatives: Women's Labor in Urban Turkey. University of Texas Press.

Wickham, C. Roseffsky, 2011. Middle East Law and Governance 3, 204-223

Yuval-Davis, N., 1998. Gender \& Nation. London: Sage Publications 